УДК 582.232-056.255

(C) 2013

Авраменко Н. I., аспірант*

Полтавська державна аграрна академія

\title{
ВИДИ ВОДОРОСТЕЙ У РІЧЦІ ВОРСКЛА, ЩО ВИКЛИКАЮТЬ «ЦВІТІННЯ» ВОДИ
}

\section{Рецензент -кандидат сільськогосподарських наук М. А. Піщаленко}

\begin{abstract}
Наведено результати досліджень із вивчення евтрофікаційних процесів, зокрема розглядаються особливості динаміки чисельності різноманітних видів водоростей у різних районах річки Ворскли.Описується видовий склад водоростей, щуо викликають «ивітіння» води в Ворсклі, в м. Полтава та їі околичях. Підкреслюється, щуо в більшості випадків евтрофікацію водойм викликають багатовидні альгоугрупування. Зареєстровано також розвиток майже «чистих» монокультур окремих видів. Розглядаються можливі біотичні та абіотичні фактори, щэо викликають явище «ивітіння» води.
\end{abstract}

Ключові слова: «ивітіння» води, водорості, фітопланктон, видовий склад, альгоугрупування.

Постановка проблеми. Зі збільшенням народонаселення Землі та посиленням антропогенного впливу на біосферу випадки «цвітіння» води стають все частішими. В якості збудників евтрофікації нерідко виступають види, які раніше не викликали цього явища. У більшості випадків «цвітіння» води супроводжується накопиченням у водоймах токсичних сполук, що виникають як у результаті життедіяльності водоростей, так і внаслідок розпаду їх відмерлих клітин. «Цвітіння» води супроводжується такими негативними наслідками, як зсув екологічної рівноваги в сторону накопичення органічних речовин, вторинним забрудненням, погіршенням якості природних вод.

Аналіз основних досліджень і публікацій, у яких започатковано розв'язання проблеми. «Цвітіння» води, викликане масовим розвитком мікроскопічних рослин, - явище широко розповсюджене на нашій планеті. Воно поширене в усіх типах водойм, природних і штучних, морських і континентальних [6]. Тому евтрофікація викликає неабияку цікавість у вчених. Однак особливий інтерес в якості збудників «цвітіння» води привертають синьо-зелені, дінофітові та золотисті водорості в зв'язку з їх токсичністю [3]. Токсичні виділення збудників «цвітіння» мають суттєвий вплив на формування видового складу та чисельності багатьох представників гідробіоценозів із збереженням цього впливу на тривалий період після завершення «цвітіння», що обумовлює випадання окремих, найбільш чутливих до токсинів груп організмів [1]. Можливо, саме здатність до утворення токсинів дає змогу окремим видам займати домінантне положення в гідробіоценозі [2]. Відомо, що «цвітіння» води можуть викликати такі види як Chlamydomonas Ehr., Carteria Dies., Pandorina Bory, Eudorina Ehr., Volvox (L.) Ehr., Nautococcus Korsch. та ін. [5]. Проте відомостей про видовий склад збудників зеленого «цвітіння» води та їх поширення вкрай мало [4].

Мета дослідження - встановлення видового складу та поповнення даних про водорості як реальних і потенційних збудників «цвітіння» води річки Ворскла.

Завданнями наших досліджень $є$ : встановити вплив окремих видів водоростей на евтрофікацію водойм; встановити видовий склад збудників «цвітіння» води; визначити кількісний склад мікроорганізмів у воді; встановити вплив мікроорганізмів на якість води.

Предмет дослідження - евтрофікаційні процеси річки Ворскла.

Матеріали і методи дослідження. Збір і вивчення планктону річки Ворскла проводився наступним чином: деякі водорості (наприклад, вольвокс і водяна сіточка) можуть бути помітні неозброєним оком, a переважна більшість планктонних водоростей мають досить малі розміри й видні тільки під мікроскопом. Існує кілька прийомів збору планктонів, але найпоширенішим $є$ збір за допомогою «планктонної сітки». Головною частиною цього знаряддя лову $є$ конічний мішок, що виготовлений з особливої міцної шовкової тканини із дрібними отворами: на $1 \mathrm{~cm}^{2}$ припадає близько 6 тис. отворів. Через планктонну сітку фільтрується вода, дрібні отвори тканини вільно пропускають воду, але затримують більшість планктонних водоростей, які збирають у стаканчик, прикріплений до вузької частини конуса.

* Науковий керівник - доктор сільськогосподарських наук, професор П. В. Писаренко 


\section{СТОРІНКА МОЛОДОГО ВЧЕНОГО}

Відбір проб води у місті Полтава та їі околицях проводився з 2009 по 2012 рр. у різні пори року. Одночасно вимірювали $\mathrm{pH}$ і температуру води. Відібрані зразки вивчали під мікроскопом у живому стані. Іноді спостереження проводили протягом більш тривалого часу зі збереженням живого матеріалу на північному вікні лабораторії та проводили повторний відбір зразків у водоймі під час «цвітіння».

Вивчення відібраних зразків проводили за допомогою світлових мікроскопів «Studar» та «Laboval» із використанням імерсійної оптики. Розмір організмів вимірювали пластинчастим окуляр-мікрометром 7х. Чисельність водоростів підраховували за допомогою камери Горяєва (з підрахунком 3-6 препаратів із кожного зразка). У роботі наведені середньоарифметичні значення кількості клітин у перерахунку на 1 літр.

Результати досліджень. Однією з найбільших водойм на території Полтавської області є річка Ворскла. В їі водах переважають такі види водоростей, як динофітові, діатомові, золотаві, жовто-зелені, зелені і синьо-зелені. Влітку у Ворсклі домінують синьо-зелені водорості. Особливо активні в цю пору року три види: мікроцистисфлос-акве, анабенафлос-акве, афанізоменонфлос-акве. Ці види можуть вегетувати разом, але частіше один із них при настанні сприятливих умов починає інтенсивно розмножуватися й у короткий строк досягає значних кількостей, тобто водойма починає «цвісти».
Microcystis flos-aquae (мікроцистис «цвітіння» води) зустрічається у даній річці у вигляді колоній, i за температури води $23-25^{\circ} \mathrm{C}, \mathrm{pH} 7,2$ чисельність цього виду водоростей становила $4,0 \cdot 10^{6}$ кл/л.

Влітку колонії Microcystis flos-aquae досягають таких розмірів, що їх можна побачити неозброєним оком - вони утворять суспензію, пофарбовану в брудно-зелений колір. Microcystis flos-aquae - жабуриння, що складається з вегетативних клітин із газовими вакуолями зі спор i гетероцист. У пору «цвітіння» води ії вигнуті нитки утворюють досить великі грудочки різних зеленуватих відтінків, що плавають на поверхні водойми.

Синьо-зелені водорості - домінанти літніх планктонів, а навесні й восени у річці Ворскла переважають над всіма іншими організмами діатомеї, представлені, в основному, чотирма колоніальними видами.

Найпримітніша 3 них - Asterionella Formosa («астер» у перекладі з грецької - «зірка»), чисельність якої у даній річці становить $1,4 \cdot 10^{6}$ кл/л.

Ї̈і паличкоподібні клітини утворюють зірчасті колонії.

Інша досить розповсюджена в планктоні діатомея - Melosira Islandica $\left(4,8 \cdot 10^{6}\right.$ кл/л). Її клітини у формі коротких циліндриків зібрані в нитчасті прямі колонії завдяки слизу, що склеює поверхню сусідніх клітин.

Видовий склад водоростей, що викликають евтрофікацію води у річці Ворскла

\begin{tabular}{|c|c|c|c|}
\hline Види водоростей & Чисельність (кл/л) & Температура, ${ }^{\circ} \mathrm{C}$ & $\mathrm{pH}$ \\
\hline Microcystis flos-aquae & $4,0 \cdot 10^{6}$ & $23-25$ & 7,2 \\
\hline Asterionella Formosa & $1,4 \cdot 10^{6}$ & $23-25$ & 7,5 \\
\hline Melosira Islandica & $4,8 \cdot 10^{6}$ & $23-25$ & 7,6 \\
\hline Tabellaria & $3,1 \cdot 10^{6}$ & $23-25$ & 7,2 \\
\hline Synurauvella & $1,9 \cdot 10^{6}$ & $23-25$ & 7,5 \\
\hline Dinobryondivergens & $2,4 \cdot 10^{6}$ & $20-25$ & 7,6 \\
\hline Peridinos & $6,1 \cdot 10^{6}$ & $20-25$ & 7,5 \\
\hline Cryptomonas Platyurus & $4,8 \cdot 10^{6}$ & $20-22$ & 7,6 \\
\hline Chlamydomonas Reinhard & $1,3 \cdot 10^{5}$ & $20-25$ & 7,2 \\
\hline Goniumpectorale & $4,0 \cdot 10^{6}$ & $23-26$ & 7,2 \\
\hline Pandorina Morum & $4,2 \cdot 10^{6}$ & $20-22$ & 7,2 \\
\hline Eudorina Elegans & $1,0 \cdot 10^{6}$ & $20-25$ & 7,6 \\
\hline Volvox Globator & $8,1 \cdot 10^{6}$ & $20-25$ & 7,8 \\
\hline ChlorellaVulgaris & $6,8 \cdot 10^{6}$ & $20-25$ & 7,8 \\
\hline Scenedesmus Quadricauda & $2,5 \cdot 10^{6}$ & $20-25$ & 7,8 \\
\hline Hydrodictyon & $2,0 \cdot 10^{6}$ & $20-22$ & 7,6 \\
\hline
\end{tabular}




\section{СТОРІНКА МОЛОДОГО ВЧЕНОГО}

Третя колоніальна діатомея наших планктонів - Tabellaria (від латинської «табелла» - табличка) продірявлена, ऑii чисельність становить $3,1 \cdot 10^{6}$ кл/л. Клітини їі мають вигляд прямокутних табличок, з'єднаних кутами у формі ламаної лінії або зигзагу.

У пробах планктонів водойм, зібраних навесні або восени, особливо в сонячні дні, багато золотавих водоростей двох видів - Synurauvella $\left(1,9 \cdot 10^{6}\right.$ кл/л) i Dinobryondivergens $\left(2,4 \cdot 10^{6}\right.$ кл/л). Це колоніальні організми, які мають джгутики, що допомагають їм утриматися в товщі води. Проте активно пересуваються тільки колонії Synurauvella: у краплі води під мікроскопом видні дрібні золотаві кульки, що швидко плавають у різних напрямках.

Dinobryondivergens - це утворення 3 розбіжними в різні сторони гілочками. Джгутики в цих водоростей не діють, - колонію переносить потік води, а втриматися в товщі води колонії допомагає їі форма.

Якщо зачерпнути воду з річки, де вона добре прогрівається, наприклад, біля берега, то в i краплі під мікроскопом можна спостерігати рослинні організми, пофарбовані майже так само, як діатомеї. Організми ці відносяться до групи Peridinos, тобто, це дінофітові водорості. 3 перідіней привертає увагу насамперед рогатик. Назва визначається будовою панцира, на якому є вирости (грецьке «церас» означає «ріг»). Ceratium (рогатик) активно пересувається в товщі води за допомогою джгутика, надаючи перевагу чистим водоймам.

Разом із Ceratium живе й друга перидінея Peridíniumcínctum. Панцир у неї майже кулястий, складається iз пластин, 3'єднаних широкими швами.

Загальна чисельність цього виду водоростей у пробах становила $6,1 \cdot 10^{6}$ кл/л. Перидінеї уникають забруднених вод (вони люблять чисті водойми) 3 лужною, багатою на кисень водою.

У забруднених водоймах із застояною гниючою водою, у прибережній зоні річки Ворскла можна зустріти рухливі одноклітинні криптофітові водорості. Найпоширеніший із них Cryptomonasplatyurus (криптомонас плоскохвостий) $-4,8 \cdot 10^{6}$ кл/л.

Хто влітку не бачив яскравої зеленої річкової води? У цей колір іiі забарвлює Euglena, що дала назву цілому відділу водоростей - евгленовим. У наших пробах загальна чисельність даного відділу становила $3,2 \cdot 10^{6}$ кл/л. Живуть евглени переважно в стоячих водах, хоча можуть зустрічатися й на вологій землі біля берега. У водах, багатих органічними речовинами, евглени є головним зеленим населенням води й донного мулу.

У краплі води, взятої з добре прогрітої неглибокої частини водойми, багатої мулом, можна побачити кульки, що швидко пересуваються, пофарбовані в темно-бурий або коричневий колір. Це Trachelomonas-- широко розповсюджений у наших водоймах рід евгленових водоростей, у якому налічується понад сто видів. Найбільш характерним для нашої області є трахеломонас мілкощетинистий. Виявити трахеломонаса мілкощетинистого можна в водоймах, багатих на з'єднання заліза; плаває, в основному, в придонних шарах або серед заростей вищої водної рослинності.

У водоймах річки Ворскла живе ще один представник евгленових водоростей - факус. Він відрізняється від евглени сплюсненим тілом, яке постійно зберігає свою форму. Найбільш типовий представник - факус довгохвостий. Факус довгохвостий зустрічається зазвичай у водоймах зі стоячою водою, у прибережній смузі річки, у планктоні й серед заростей. Надає перевагу нейтральним або слаболужним водам. Зимує на дні водойм. Факус, як правило, веде одинокий спосіб життя, випадки його масового розвитку майже невідомі.

Суттєву роль у планктоні водойм відіграють зелені водорості. Важливе значення у фітопланктоні мають рухливі вольвоксні й нерухливі хлорококові (протококові) водорості.

3 вольвоксових водоростей у фітопланктоні водойм Полтавської області живуть представники таких родів, як Chlamydomonas, Gonium, Pandorina, Eudorina, Volvox.

Типовим представником роду хламідомонас у нашій флорі $є$ Chlamydomonasreinhard. За температури води $20-25^{\circ} \mathrm{C}$ та рН 7,2 їх чисельність становила $1,3 \cdot 10^{5}$ кл/л. Розповсюджений хламідомонад Рейнгарда повсюдно: він зустрічається в калюжах, ставках, болотах, озерах, річках.

Рід Gonium представлений у водоймах області видом Goniumpectorale. За температури води 23$26{ }^{\circ} \mathrm{C}, \mathrm{pH} 7,2$ чисельність цього виду водоростей становила $4,0 \cdot 10^{6}$ кл/л. Іноді розвивається у величезних кількостях, може подовгу жити в лабораторних акваріумах.

Pandorinamorum також являе собою 16- або 32-клітинні ценобії (останні зустрічаються рідко). За температури води 20-22 ${ }^{\circ} \mathrm{C}, \mathrm{pH} 7,5$ чисельність цього виду водоростей становила $4,2 \cdot 10^{6}$ кл/л. Вегетативне розмноження починається, коли у водоймі накопичується чимало живильних речовин. Кожна з 16-ти клітин ценобія 


\section{СТОРІНКА МОЛОДОГО ВЧЕНОГО}

ділиться. Наприкінці періоду вегетації Pandorinamorum дає й статеві клітини - гамети, схожі між собою. Після злиття гамет утворюються рухливі чотирьохджгутикові зиготи. Наступної весни всередині зигот утворюються молоді ценобії, що починають новий ряд вегетативних поколінь.

Eudorinaelegans досить близька до Pandorinamorum. За температури води $20-25^{\circ} \mathrm{C}, \mathrm{pH} 7,6$ чисельність цього виду водоростей становила $1,0 \cdot 10^{6}$ кл/л.

Ценобії іï складаються з 16-ти, 32-х або 64-х клітин. Ценобій досить швидко пересувається в товщі води завдяки погодженій дії довгих джгутиків. Eudorinaelegans - вид дводомний: ऑï ценобії бувають чоловічі й жіночі. Після злиття великої гамети й мікрогамети утвориться зигота, що так само, як і в пандорини, проходить період спокою. Стадія спокою триває всю зиму; з настанням весни із зиготи розвивається новий ряд ценобіїв. Зустрічається евдорина витончена всюди - у ставках, озерах, річках.

Iз роду Volvox найбільш часто зустрічається Volvoxglobator, що особливо активно розмножується серед літа. У цю пору в пробах води, узятих iз річки Ворскла, ми спостерігали кулі вольвоксу неозброєним оком. При температурі води 20$25^{\circ} \mathrm{C}, \mathrm{pH} 7,8$ чисельність цього виду водоростей становила $8,1 \cdot 10^{6}$ кл/л. Ценобій вольвоксу кулястого досить великий $-2-3$ мм у діаметрі. Цей вид водоростей можна зустріти в планктоні текучих і стоячих водойм річки Ворскли.

У водоймах області часто зустрічаються і хлорококові водорості. Особливо поширені види родів Chlorella, Scenedesmus, Pediastrum, Hydrodictyon.

Хлорела - невибаглива водорость, здатна до інтенсивного розмноження, - вона $є$ практично всюди. За температури води $20-25^{\circ} \mathrm{C}, \mathrm{pH} 7,8$ чисельність цього виду водоростей у річці Ворскла становила $6,8 \cdot 10^{6}$ кл/л.

У водоймах хлорела веде планктонний спосіб життя, на сирому грунті, корі, різних підводних предметах може утворювати зелений наліт.

Досить широко розповсюджений у водоймах Полтавської області Scenedesmus quadricauda. Сценедесмус чотирихвостий добре тримається в товщі води завдяки виростам оболонки крайових клітин. Ценобії сценедесмуса складаються з 4-8 довгастих клітин, що утворюють щось схоже на ширму. Вид широко розповсюджений у планктоні прісноводних водойм - озер, рік, ставків. За температури води $20-25^{\circ} \mathrm{C}, \mathrm{pH} \mathrm{7,8}$ чисельність цього виду водоростей у річці Ворскла становила $2,5 \cdot 10^{6}$ кл/л.
Рід Pediastrum теж складається із ценобіальних організмів. Його назва походить від грецьких слів «пед» - «нога» й «астер» - «зірка», тобто організм із ніжками, розташованими зіркоподібно. Часто зустрічаються три представники цього роду: педіаструм подвійний, педіаструм Борі, педіаструм тетраедричний. Їх надзвичайно багато в чистих ставках, болотах, ріках, озерах. Зазвичай вони тримаються ближче до дна, у заростях очеретів, але можуть зустрічатися в поверхневих шарах води. За температури води $20-25^{\circ} \mathrm{C}, \mathrm{pH} 6,8$ чисельність даних водоростей становила $1,6 \cdot 10^{6}$ кл/л.

Hydrodictyon - водяна сіточка. Свою назву ця водорость одержала від двох грецьких слів «Гюдер» - «вода» й «диктіон» - рибальська сітка. Водяну сіточку справедливо називають гігантом із-поміж зелених хлорококових водоростей. Ценобії цієї водорості, що досягають іноді довжини 1 м і ширини близько 8 см, мають вигляд замкнутого циліндричного мішка із сітчастими стінками. Водяна сіточка живе в стоячих і повільних водах, де або рухається у воді, або прикріплюється до стебел водяних рослин. У пробах води з річки Ворскла чисельність цього виду водоростей становила $2,0 \cdot 10^{6}$ кл/л.

Висновок. Протягом 2010-2012 рр. ми детально вивчали явище «цвітіння» води у різних районах річки Ворскли, що було спричинене найрізноманітнішими видами водоростей. При цьому вода набувала різних кольорів - від блідозеленого до яскраво-зеленого та коричнуватозеленого. «Цвітіння» води річки Ворскла зазвичай починалось у місцях із повільним стоком, у теплу пору року, з травня по жовтень, за температури води $15-28^{\circ} \mathrm{C}$, pH 7,2-7,8.

У річці Ворскла найчастіше «цвітіння» води викликають саме зелені водорості. Серед збудників евтрофікації $є$ рідкісні для України види. Зазвичай «цвітіння» викликають багатовидові угрупування водоростей, але є види, які розвиваються у вигляді чистої «монокультури». В такому випадку можна припустити, що вирішальну роль у виникненні «цвітіння» води відіграє біотичний фактор, а відповідні види можна розглядати як потенційних продуцентів фізіологічно активних речовин. Такі види, як Pandorinamorum та Chlamydomonasnoctigama, можуть викликати «цвітіння» води як у вигляді «монокультури», так і в сукупності $з$ іншими видами водоростей. Слід зазначити, що склад угрупувань, що викликають «цвітіння» води, може залишатися стабільним протягом кількох років. 


\section{БІБЛІОГРАФІЯ}

1. Горюнова С. В., Демина Н. С. Водоросли продуценты токсических веществ. - М. : Наука, 1974. $-256 \mathrm{c}$.

2. Гусева К. А., Приймаченко А. Д., Кожова О. М.

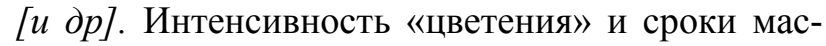
совой вегетации сине-зеленых водорослей в водохранилищах гидроэлектростанций СССР // Формирование и контроль качества поверхностных вод. - Вып. 2. - К. : Наукова думка, 1976. C. 6-19.

3. Кондратьева Н. В., Коваленко О. В. Краткий определитель видов токсических сине-зеленых водорослей. - К. : Наукова думка, 1975. - 80 с.

4. Коришков О. А. Визначник прісноводних водоростей УРСР. - Т. 4. - К. : Вид-во АН УРСР, 1938. - $184 \mathrm{c}$.

5. Коршиков O. A. Підклас протококові (Protococcineae). Вакуольні (Vacuolalcs) та Протококові (Protococcacales). - К. : Вид-во АН УРСР, 1953. - 440 с. (Визначник прісноводних водоростей Української РСР. - Т. 5).

6. Сиренко Л. А., Козиџкая В. Н. Биологически активные вещества водорослей и качество воды. К. : Наукова думка, 1988. - 256 с. 